\title{
Salt Lubricant Pads for U Extrusion
}

\author{
Glenn Moore
}

July 2017

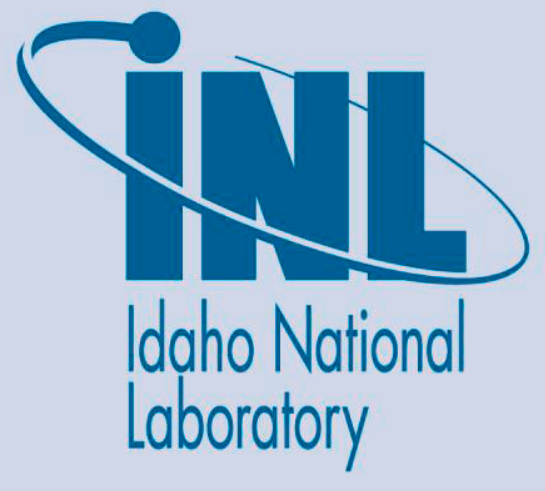

The INL is a U.S. Department of Energy National Laboratory operated by Battelle Energy Alliance 


\section{DISCLAIMER}

Neither the U.S. Government nor any agency thereof, nor any of their employees, makes any warranty, expressed or implied, or assumes any legal liability or responsibility for the accuracy, completeness, or usefulness, of any information, apparatus, product, or process disclosed, or represents that its use would not infringe privately owned rights. References herein to any specific commercial product, process, or service by trade name, trade mark, manufacturer, or otherwise, does not necessarily constitute or imply its endorsement, recommendation, or favoring by the U.S. Government or any agency thereof. The views and opinions of authors expressed herein do not necessarily state or reflect those of the U.S. Government or any agency thereof. Being provided this document, directly or indirectly, shall not be construed to constitute a governmental export license or authorization.

\section{GENERATED INFORMATION - UNLIMITED RIGHTS}

This document contains, at least in part, Generated Information - Unlimited Rights arising under 13-CR-13 between TerraPower, LLC, and Battelle Energy Alliance, LLC. 


\title{
Salt Lubricant Pads for U Extrusion
}

\author{
Glenn Moore
}

July 2017

Idaho National Laboratory Idaho Falls, Idaho 83415

http://www.inl.gov

\author{
Prepared for \\ TerraPower, LLC \\ Under CRADA 13CRADA13 \\ And DOE Idaho Operations Office \\ Contract DE-AC07-05ID14517
}





\section{CONTENTS}

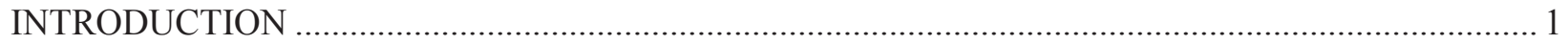

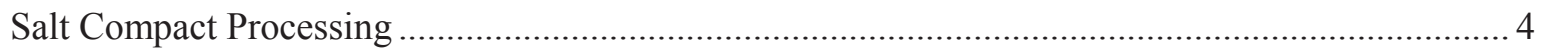

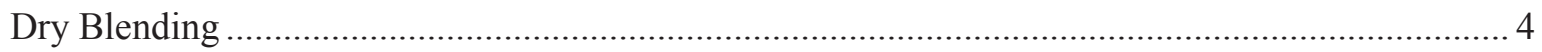

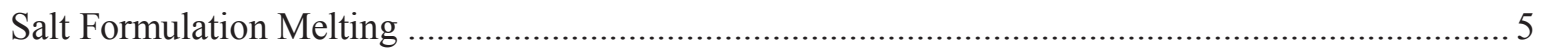

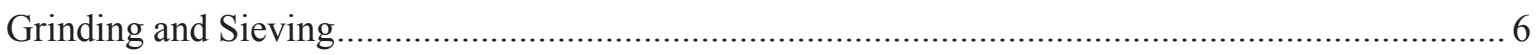

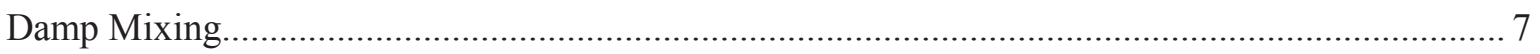

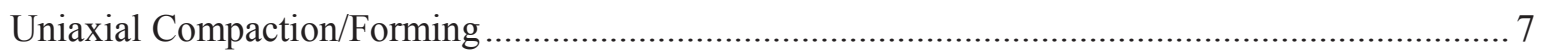

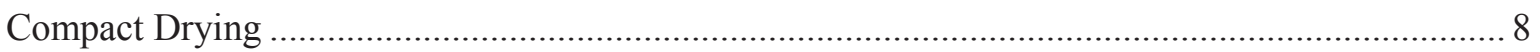

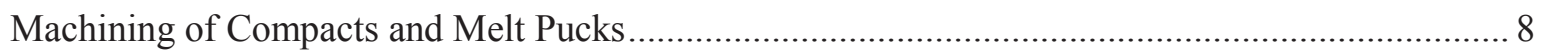

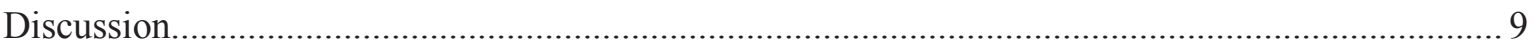

\section{FIGURES}

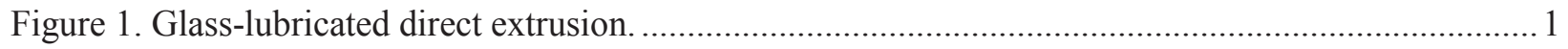

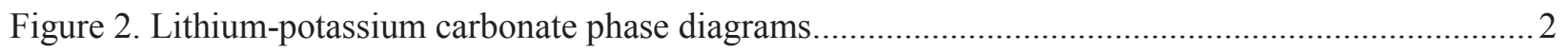

Figure 3. Sketch of standard glass or salt compact. ....................................................................... 3

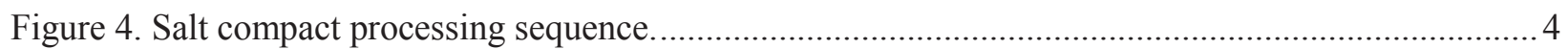

Figure 5. Turbula mixer used for dry-blending salt powders............................................................. 5

Figure 6. K-Li carbonate salt puck after removal from alumina crucible................................................... 5

Figure 7. Salt puck grinding and sieving experimental setup. .............................................................. 6

Figure 8. Sieve analysis of ground carbonate salt melt powder............................................................. 6

Figure 9. Picture of $35 \mathrm{~mm}$ diameter pressing die, Delrin punch and disk, and pressed salt

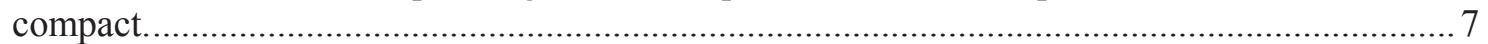

Figure 10. Final form salt compact after drying and hole drilling. ........................................................ 8 


\section{Salt Lubricant Pads for U Extrusion \\ INTRODUCTION}

This report primarily describes the processing of carbonate-salt solid-lubricant pads or compacts for use in the hot metal extrusion process. ${ }^{1,2,3,4,5,6,7,8,9}$ It also provides an overview of the solid lubricant development process, encompassing the processing and evaluation of glass and carbonate salt materials. Traditionally, glass has been used as an expendable interfacial lubricant. Here, carbonate salt formulations are evaluated as an alternative material type, with two potential advantages: 1) the ability to easily prepare binary salt mixtures that have melting temperatures in the range of $500-900^{\circ} \mathrm{C}$, and 2) easy removal of the lubricant from extruded rods and tubes, given that carbonate salts are appreciably water soluble.

The function of the salt compact is to provide lubrication for the extruding billet via the formation of a continuous molten salt film or coating; analogous to glass-lubrication, Figure 1. ${ }^{10,11}$ The salt compact is placed at the die face, and as billet extrusion proceeds, the compact is consumed via melting at the compact/billet interface.

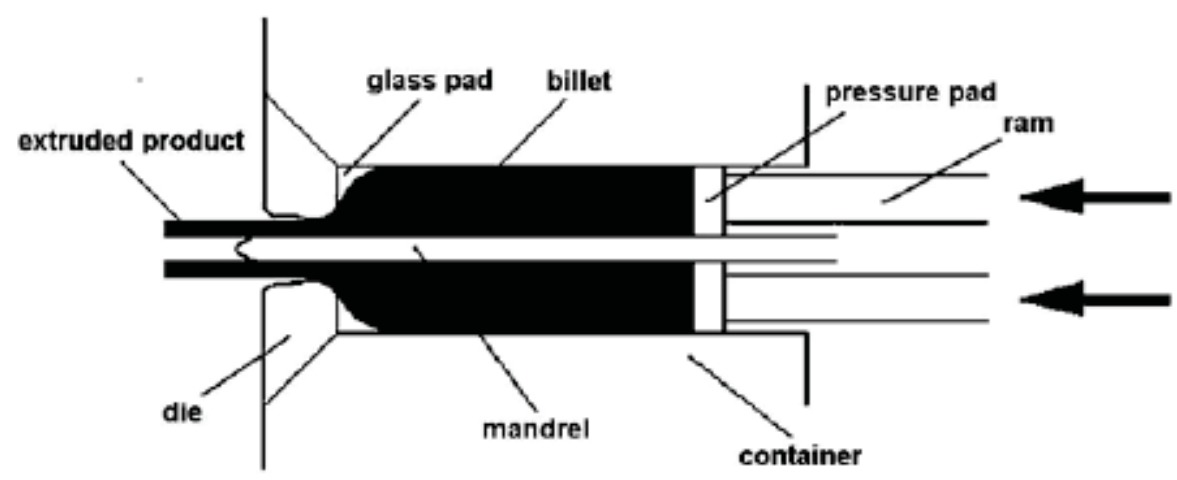

Figure 1. Glass-lubricated direct extrusion.

Lithium, potassium, and sodium carbonate salts were identified as the preferred salts for this study; given that the salt bath, utilized for preheating billets, containing a mixture of these salts. ${ }^{12}$ Phase diagrams are utilized for determining salt mixture formulations having target melting temperatures. The lithiumpotassium carbonate phase diagram is shown in Figure 2. Mole fraction data from the phase diagram is converted to mass-based data via the molecular weight of the constituents. Table 1 provides a mass-ratiobased table for preparation of a target melting temperature for $\mathrm{Li}-\mathrm{K}$ carbonates. 


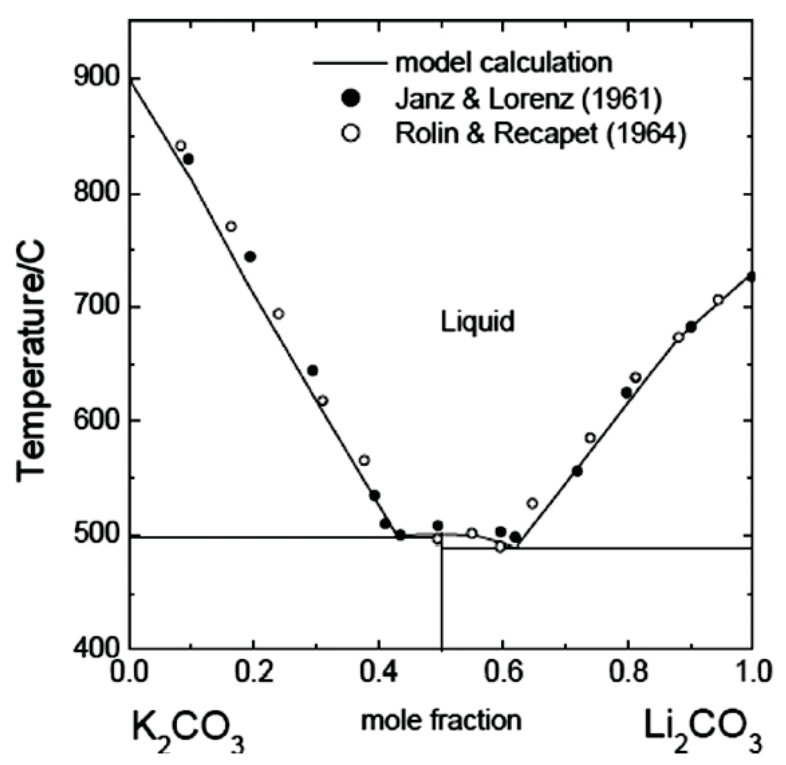

Figure 2. Lithium-potassium carbonate phase diagrams. ${ }^{13}$

Table 1. Mass-based Li-K carbonate formulation.

\begin{tabular}{|c|c|c|}
\hline $\mathbf{L i}_{2} \mathrm{CO}_{3}$ & $\mathbf{K}_{\mathbf{2}} \mathrm{CO}_{3}$ & $\begin{array}{c}\text { Melting } \\
\text { Point }\end{array}$ \\
\hline (wt\%) & (wt\%) & $\left({ }^{\circ} \mathrm{C}\right)$ \\
\hline $0.0 \%$ & $100.0 \%$ & 899 \\
\hline $5.6 \%$ & $94.4 \%$ & 829 \\
\hline $11.8 \%$ & $88.2 \%$ & 742 \\
\hline $18.6 \%$ & $81.4 \%$ & 644 \\
\hline $26.3 \%$ & $73.7 \%$ & 533 \\
\hline $27.9 \%$ & $72.1 \%$ & 508 \\
\hline $29.6 \%$ & $70.4 \%$ & 500 \\
\hline $34.8 \%$ & $65.2 \%$ & 505 \\
\hline $44.5 \%$ & $55.5 \%$ & 503 \\
\hline $46.6 \%$ & $53.4 \%$ & 498 \\
\hline $57.9 \%$ & $42.1 \%$ & 557 \\
\hline $68.1 \%$ & $31.9 \%$ & 625 \\
\hline $82.8 \%$ & $17.2 \%$ & 683 \\
\hline $100.0 \%$ & $0.0 \%$ & 726 \\
\hline
\end{tabular}

Currently, the standard salt compact being employed consists of lithium carbonate and potassium carbonate. Additionally, potassium-rich formulations are employed because of the limited water solubility of lithium carbonate (see Appendix A, "Materials," for information on the properties of the materials). For extrusion trials compacts with a formulated melting temperature in the range of $650-800{ }^{\circ} \mathrm{C}$ were prepared.

To facilitate, as much as possible, a uniformly melting carbonate salt formulation, the salt constituents are dry blended, melted together, and then cooled and solidified. The obtained solid mass is typically crushed and ground back into a powder form, but alternatively can be machined directly into the desired end-use form. 
NOTE: If the salt constituents are not pre-melted together, then a slower melting rate (more characteristic of the lowest melting temperature salt constituent) would be expected. In a homogenized salt formulation, it is anticipated that the lubricating film forms uniformly once the salt formulation melting temperature is reached.

The rate of melting at the billet/salt-compact interface and the viscosity of the associated molten lubrication film are both viewed as important, relative to control/optimization of the extrusion process and the surface quality and diametrical uniformity of the extruded product.

Based on traditional water-glass bonded glass pad application, glass pads or compacts that are readily crushable are primarily employed. A like approach was taken here, with crushability being "adjustable" based on power compaction force and binding-liquid "water" addition. Typically 50-70\% dense compacts were prepared.

The geometry of the salt compacts, as typically prepared in this evaluation, is shown in Figure 3 . The design was derived based on the standard billet-nose geometry. The salt compact is placed in the extrusion liner prior to mating with the extrusion die. The inside diameter of the currently configured extrusion liner is $\varnothing 1.42 \mathrm{in}$. Thus, during the initial segment of the extrusion process leading up to billet "upset," the salt compact is crushed and a $\sim 0.040$-in.-wide annular gap eliminated. Further, material associated with the compact-base, $\sim 0.2$ in. thick, is partially compacted and retained and partially expelled from the $\varnothing .47$ in., or smaller, die hole.
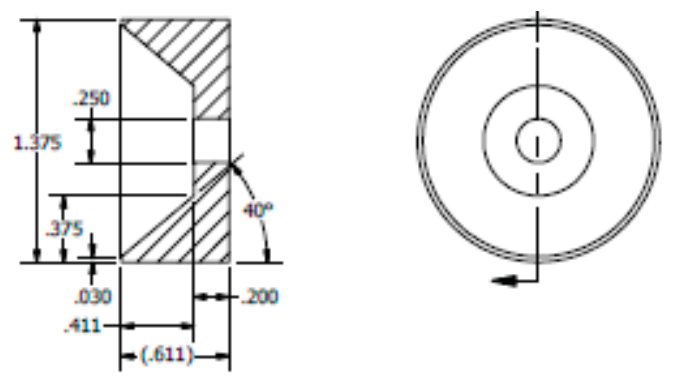

Figure 3. Sketch of standard glass or salt compact.

Desirable attributes of the solid-lubricant material system and the associated end-product "salt compacts" include the following:

- Easily controlled/adjusted melting temperature via salt composition.

- Uniform lubricant coating on extrudate surface, so as to mitigate oxidation. ${ }^{14}$

- Controllable liquid-phase viscosity ${ }^{15}$ (not yet investigated in detail)

- Additives such as graphite, ball clay, or boron nitride $(\mathrm{BN})$ can be incorporated for the purpose of controlling the liquid phase formation rate and liquid phase viscosity.

- Ease of fabrication. Namely, minimal effort required to go from starting materials to final form; options include:

- Uniaxial compaction of water dampened homogenized salt powder (primary method used to date)

- Water- or ethanol-base slurry casting of homogenized salt powder.

- Molten salt casting (perceived as good potential option if near 100\% density of salt compacts are shown to be advantageous). 
The primary steps for fabrication of salt compacts are detailed in this section. Comments and observations are provided along the way. It should be noted that the methodology used was selected based on a need to prepare a small number (2-3) of specimens of a given target salt compact composition. No significant challenges are envisioned in moving to larger batch sizes (i.e., 10-100 units per batch). A flowchart of the processing steps is shown in Figure 4.

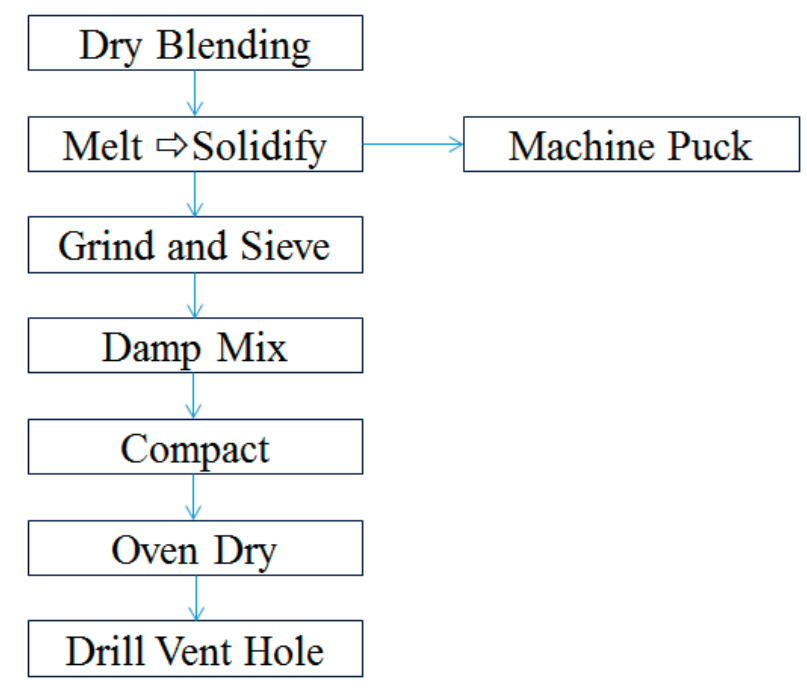

Figure 4. Salt compact processing sequence.

\section{Salt Compact Processing}

The established processing sequence for preparation of Li-K carbonate solid lubricant pads or compacts is detailed in this section. Prior to material processing activities, an order is established for a given number of salt compacts, typically $2-3$, having a target melting point. The compact composition, meaning the ratio of $\mathrm{Li}$ and $\mathrm{K}$ carbonate, is calculated based on data provided in Table 1 above.

\section{Dry Blending}

Lithium and potassium carbonate powders in the needed mass proportion are weighed and placed in a screw-top mixing jar, typically 100-200 g charge size. The powder mixture is then blended in a Turbula mixer for $\sim 5-10$ minutes. The blended salt mixture powder is then transferred to alumina crucibles in preparation for melting. 


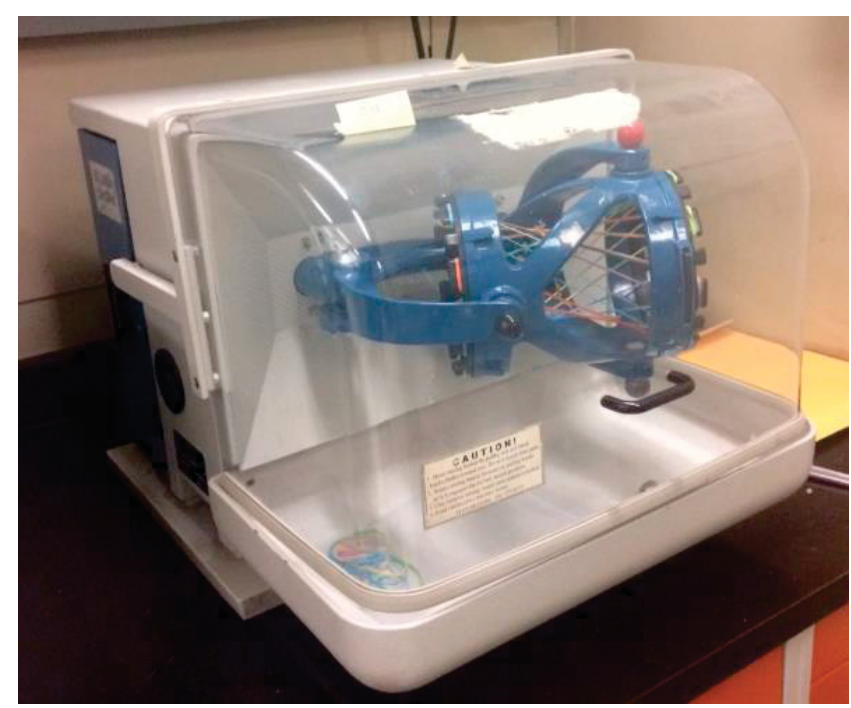

Figure 5. Turbula mixer used for dry-blending salt powders.

\section{Salt Formulation Melting}

Alumina crucibles loaded with the carbonate salt mixture are placed in an air atmosphere box furnace. The furnace is heated, in a period of $\sim 2$ hours, to a temperature $50-100^{\circ} \mathrm{C}$ above the calculated melting temperature of the salt mixture. A furnace hold time of 30-45 minutes, at temperature, is then performed. Subsequently, furnace power is turned off and the salt melt cooled to room temperature at a rate limited by the thermal mass of the furnace, for $\sim 6-8 \mathrm{hrs}$. During the cooling process, the difference in thermal contraction between the salt mixture and the alumina crucible leads to an easily removed salt "puck." The salt puck is typically released from the crucible after scraping away any residual salt material adhering to the upper sidewalls of the crucible. An extracted salt puck is shown in Figure 6.

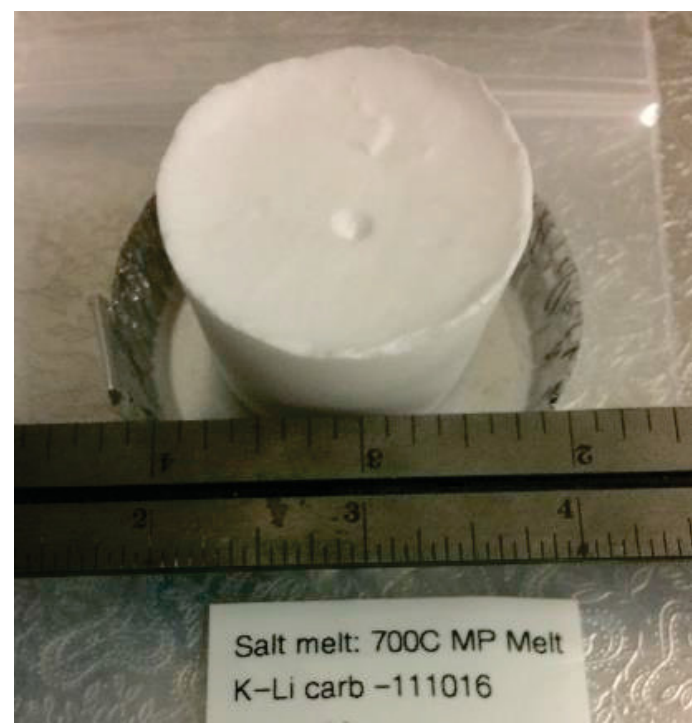

Figure 6. K-Li carbonate salt puck after removal from alumina crucible. 


\section{Grinding and Sieving}

Once removed from the crucible, the salt puck is crushed and ground into a powder. The crushing and grinding operation is performed manually, in a fume hood, using a ceramic mortar and pestle (see Figure 7).

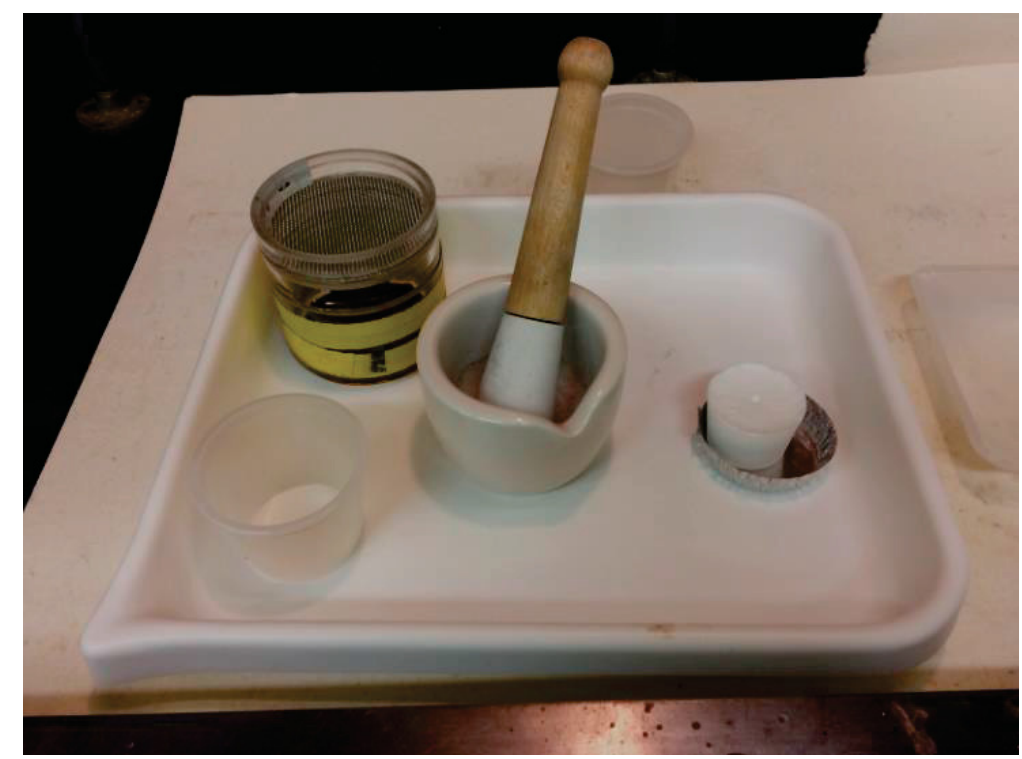

Figure 7. Salt puck grinding and sieving experimental setup.

The crushing and grinding step for a $\sim 100 \mathrm{~g}$ salt puck takes $\sim 15$ minutes. Initially, the salt puck is broken down into $\sim 10$-g-sized pieces. Isolated $\sim 10$-g pieces are then crushed and ground further; periodically, ground salt is transferred from the mortar to a sieve with a 500-600 um opening. Material not passing through the sieve is returned to the mortar. The process is performed until all of the salt material passes through the sieve. An approximate yield of $99 \%$ is realized. Figure 7 provides a sieve analysis of the ground and sieved powder using the method. The resulting salt powder, by weight, is $\sim 50 \%$ less than 115 um $(<120$ mesh $)$.

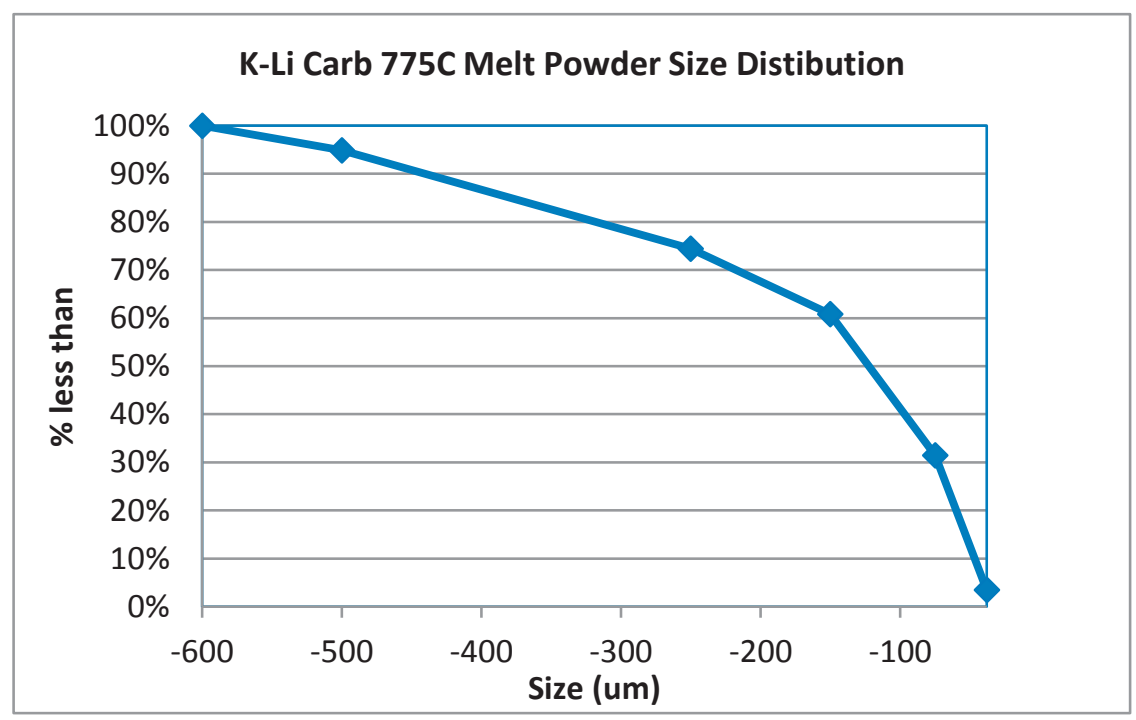

Figure 8. Sieve analysis of ground carbonate salt melt powder. 


\section{Damp Mixing}

The standard method for preparing a salt compact or pad involves wet mixing of a prescribed mass of ground salt powder with a sufficient amount of water to form a compactable mixture. If insufficient water is used, the resulting frail compact may lack adequate handling durability and could allow compact edge chipping before and after drying. Conversely, if too much water is used, the resulting salt compact will be prone to sticking on the compaction die punches, hindering compact removal. The best amount of water per a given mass of salt powder is $\sim 15 \%$ of the to-be formed powder mass, with $10 \%$ being too dry and $20 \%$ being too wet.

During preparation of the wet mix, heat is generated via the dissolution of a fraction of salt powder with applied water addition. The water-salt reaction promotes local salt clumping in areas of high water concentration. Thus, it has been found that it is best to add the prescribed water in 2-3 applications of drops. Between each water addition, a spatula tools is used to distribute the water and wet as much of the dry salt powder as possible. When water addition and mixing are appropriately balanced, a reasonably uniform compaction mixture was obtained. Due to the heat generated in the mix via the water addition, evaporation is enhanced. Consequently a short, 2-3 minute working-time is observed and expeditious die loading and compaction is called for.

\section{Uniaxial Compaction/Forming}

Compact forming of damp mixes is preformed via uniaxial pressing. A commercial 35-mm-diameter compact die set is employed (Ø1.38 in.), Figure 9. The die set used incorporates die-volume evacuation capability. Vacuum prior to compaction is established via a hand-operated vacuum pump or an electric diaphragm vacuum pump; this minimizes porosity in formed compacts. Compaction of damp mixes into salt compacts has been found to be optimal at a uniaxial compaction force of 4 kip.

It has been determined that die-punches constructed of Delrin and used in conjunction with the spraybased mold release agent (product name: Houdini) "lock lub" afforded the best release of salt compacts.

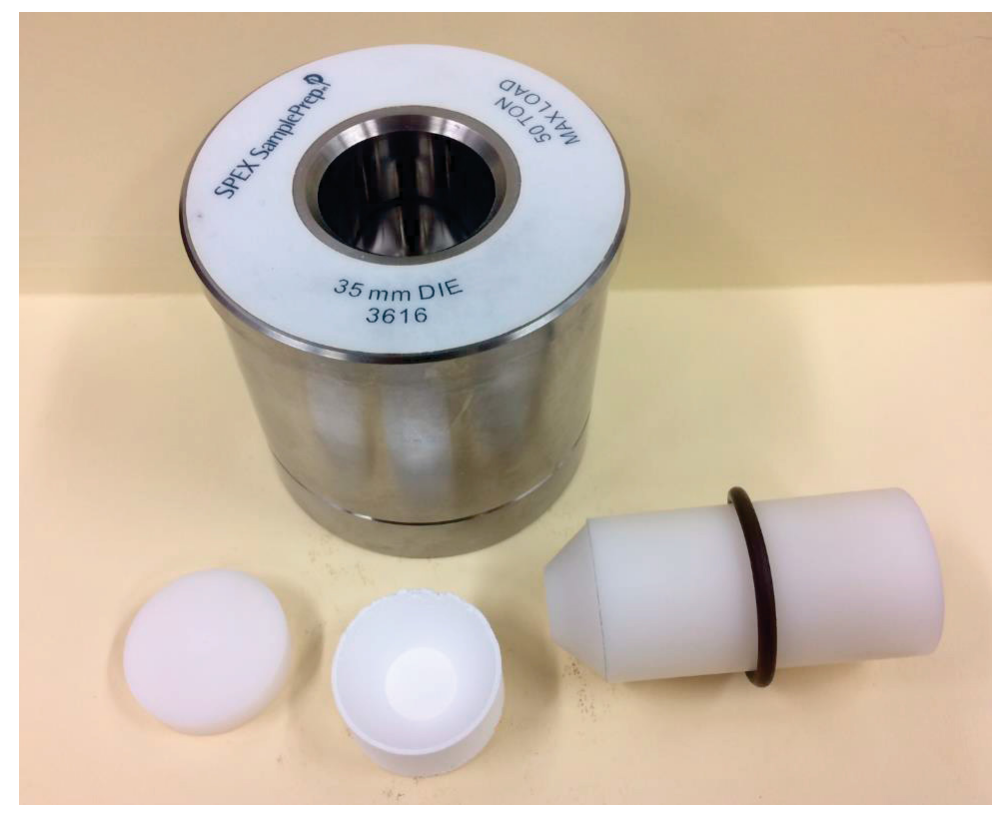

Figure 9. Picture of 35mm diameter pressing die, Delrin punch and disk, and pressed salt compact. 


\section{Compact Drying}

It has been determined that 4 kip uniaxial-pressed compacts could be directly dried to a usable condition at $65^{\circ} \mathrm{C}$ for a period of a few hours. Compacts pressed at 7 Kkip have exhibited cracking during initial drying at $65^{\circ} \mathrm{C}$. Additional drying at 90 and $120^{\circ} \mathrm{C}$ has been performed in some cases. The benefit of this has not been established.

NOTE: $\quad 120^{\circ} \mathrm{C}$ drying for the purpose of dehydrating a prepared salt compact may need to be evaluated, given the potential effect on extruded product surface finish.

\section{Machining of Compacts and Melt Pucks}

After compact drying, a vent hole is drilled in the salt compact or compact. Standard machining techniques are used (i.e. a lathe with a drill bit). Alternatively, an electric hand drill and drill bit can be used. When using a hand drill, making 1/8-in.-diameter holes is straightforward. Making 1/4-in.-diameter holes is challenging, given the tendency of the bit to "grab" near the hole exit. In some cases, compacts have been split in half when $1 / 4$ holes were attempted using a hand drill. A finished salt compact is shown in Figure 10.

Air or oven dried pressed salt powder compacts and melt-formed pucks were readily machined using standard machining technique. The machinability of the salt material is comparable to that of low density graphite.

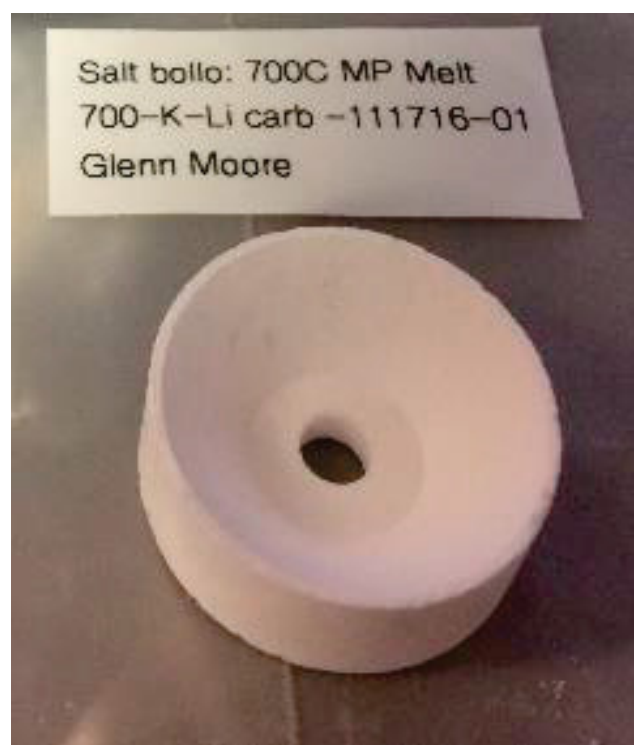

Figure 10. Final form salt compact after drying and hole drilling. 


\section{Discussion}

Initially, low melting temperature, i.e. $\sim 600-700{ }^{\circ} \mathrm{C}$ glass powder compacts were evaluated. ${ }^{16}$ Inadequate melting of the glass powder compacts was observed during extrusion experiments, subsequently carbonate salt based lubricant formulations were investigated. It was found that crushable carbonate-salt compacts could be easily formed via powder compaction and/or machined from melt-pucks.

Dried salt compacts and machined melt-pucks were utilized in $\mathrm{U}-\mathrm{Zr}$ alloy extrusions experiments. It was found that salt formulations with a melting temperature of $650-700{ }^{\circ} \mathrm{C}$ was appropriate for an $800{ }^{\circ} \mathrm{C}$ preheated U-Zr billet. Powder compacts utilized were $\sim 50-70 \%$ dense and melt-puck $\sim 100 \%$ dense.

It was found that the potassium rich salt residue was easily removed from extruded rods and extrusion tooling using damp terri towels.

Pitting or dents were observed on the surface of the extruded rods. The location of the pits/dents was coincident with high residual salt residue. It is surmised that partially melted salt aggregates were entrained or embedded in the extruding billet and subsequently passed through the die, resulting in the observed pits/dents.

A current need for a salt-base lubricant has been eliminated; via the incorporation/addition of a preheated copper follower block with the U-Zr billet. 


\section{Appendix A: Materials}

Table 1. Carbonate salts and properties.

\begin{tabular}{|c|c|c|c|c|c|c|c|c|c|c|c|}
\hline Salt & $\begin{array}{l}\text { Chemical } \\
\text { Formula }\end{array}$ & CAS Number & Vendor & Details & Product \# & $\begin{array}{c}\text { MW } \\
\text { (g/mole) }\end{array}$ & $\mathrm{SG}(\mathrm{g} / \mathrm{cc})$ & $\begin{array}{c}\text { Solubility in } \\
\text { Water @ RT } \\
(\mathrm{g} / 100 \mathrm{~mL}) \\
\end{array}$ & \begin{tabular}{|c|} 
Melting \\
Temperature \\
$\left({ }^{\circ} \mathrm{C}\right)$ \\
\end{tabular} & $\begin{array}{c}\text { Decomposition } \\
\text { Temperature } \\
\left({ }^{\circ} \mathrm{C}\right) \\
\end{array}$ & $\begin{array}{l}\text { Viscosity } \\
\text { (cP) }-\left({ }^{\circ} \mathrm{C}\right)\end{array}$ \\
\hline $\begin{array}{l}\text { Lithium } \\
\text { Carbonate }\end{array}$ & $\mathrm{Li}_{2} \mathrm{CO}_{3}$ & $554-13-2$ & $\begin{array}{r}\text { Sigma } \\
\text { Aldrich }\end{array}$ & $>99 \%$ purity & 624701 & 73.1 & 2.11 & 1.29 & 723 & $\sim 1300$ & 4.64-777 \\
\hline $\begin{array}{l}\text { Potassium } \\
\text { Carbonate }\end{array}$ & $\mathrm{K}_{2} \mathrm{CO}_{3}$ & $584-08-7$ & $\begin{array}{r}\text { Sigma } \\
\text { Aldrich }\end{array}$ & $\begin{array}{l}\text { anhydrous, } \\
>99 \% \text { purity }\end{array}$ & 791776 & 138.2 & 2.43 & 112 & 891 & $>1200$ & \\
\hline $\begin{array}{l}\text { Sodium } \\
\text { Carbonate }\end{array}$ & $\mathrm{Na}_{2} \mathrm{CO}_{3}$ & $497-19-8$ & $\begin{array}{l}\text { Sigma } \\
\text { Aldrich }\end{array}$ & $\begin{array}{c}\text { anhydrous, } \\
>99.5 \% \\
\text { purity }\end{array}$ & 791768 & 105.99 & 2.54 & $\sim 25$ & 851 & & $3.4-887$ \\
\hline
\end{tabular}




\section{Appendix B: Development Activities}

\begin{tabular}{|c|c|c|c|}
\hline $\begin{array}{c}\text { Lubrication } \\
\text { Type }\end{array}$ & $\begin{array}{l}\text { Processing } \\
\text { Category }\end{array}$ & Description & Results/Comments \\
\hline $\begin{array}{l}\text { Glass } \\
\text { Powder } \\
\text { Compacts }\end{array}$ & Glass Powder & $\begin{array}{l}\text { Evaluation of various glass powders and sodium silicate bonding } \\
\text { agents: } \\
\text { Ground borosilicate glass powder for Specialty Glass Inc, Oldsmar, } \\
\text { FL: } \\
\quad \text { SP1804 (D50 } 18 \mathrm{um}) / 660 \mathrm{C} \text { softening pt. } \\
\quad \text { SP2451 (D50 10um)/630 softening pt. } \\
\text { Advanced Technical Products, } \\
\quad \text { ATP-661 ground glass, } 200 \text { mesh, softening temperature }<600 \mathrm{C} \\
\quad \text { ATP-562 ground glass, } 200 \text { mesh, softening temperature }<600 \mathrm{C} \\
\text { Waterglass Bonding Agent: Sodium silicate }\end{array}$ & $\begin{array}{l}\text { Powder compacts were prepared via } \\
\text { compaction of glass powder, sodium silicate } \\
\text { "binder" } \\
\text { It was determined that the melting } \\
\text { temperature of the glass powders evaluated } \\
\text { was not low enough to be effective at the } \\
\leq 800 \text { C extrusion temperature employed }\end{array}$ \\
\hline
\end{tabular}




\begin{tabular}{|c|c|c|c|}
\hline $\begin{array}{c}\text { Lubrication } \\
\text { Type }\end{array}$ & $\begin{array}{c}\text { Processing } \\
\text { Category }\end{array}$ & Description & Results/Comments \\
\hline $\begin{array}{l}\text { Salt } \\
\text { Compacts }\end{array}$ & Wet Mix & $\begin{array}{l}\text { Wet salt mix development. The addition of water to salt powder, as } \\
\text { expected, results in the evolution of heat. It was observed that wet } \\
\text { salt powder tended to form semi-hard granules that were undesirable } \\
\text { for uniform compaction. } \\
\text { The use of ethanol/water solutions were evaluated for the purpose of } \\
\text { mitigating heat evolution and semi-hard granule formation. }\end{array}$ & $\begin{array}{l}\text { It was found that the crushability of the final } \\
\text { salt compact could be easily controlled via the } \\
\text { substitution of ethanol for a fraction of the } \\
\sim 15 \mathrm{wt} \% \text { water component. The greater the } \\
\text { ethanol fraction, the weaker/more crushable } \\
\text { the salt powder compacts became. Heat } \\
\text { evolution was not appreciably mitigated in } \\
\text { formulations having } \sim 10-15 \mathrm{wt} \% \text { water }(\sim 5- \\
10 \mathrm{wt} \% \text { ethanol). } \\
\text { Given that the ethanol fraction quickly } \\
\text { evaporated, semi-hard granules were still } \\
\text { produced. } \\
\text { Neat water additions were found best for } \\
\text { controlling mix constancy and produced } \\
\text { durable/machinable dried compacts. }\end{array}$ \\
\hline $\begin{array}{l}\text { Salt } \\
\text { Compacts }\end{array}$ & $\begin{array}{l}\text { Solid } \\
\text { lubricant } \\
\text { additives }\end{array}$ & $\begin{array}{l}\text { Literature and patents associated with glass pad formulations made } \\
\text { use of solid lubricant powder additions, such as boron nitride, } \\
\text { graphite, molybdenum disulfide, ball clay, etc.. }{ }^{5} \text { Such additions were } \\
\text { evaluated, in the literature, for the purpose of controlling melt film } \\
\text { formation rate, melt film viscosity, and supplemental lubrication and } \\
\text { thermal insulation between the billet and liner. }\end{array}$ & $\begin{array}{l}\text { Ball clay and graphite powder were easily } \\
\text { incorporated in salt powder compacts. When } \\
\text { a } 5 \mathrm{wt} \% \text { graphite containing salt compact was } \\
\text { used in an extrusion experiment, no } \\
\text { appreciable change in extrusion force was } \\
\text { observed. }\end{array}$ \\
\hline $\begin{array}{l}\text { Salt } \\
\text { Compacts }\end{array}$ & $\begin{array}{l}\text { Compact } \\
\text { Pressing }\end{array}$ & $\begin{array}{l}\text { Die release agents } \\
\text { Salt compacts exhibited sticking to the die and punch surfaces. }\end{array}$ & $\begin{array}{l}\text { BN, silicone, Houdini, zinc stearate, } \\
\text { Houdinin } \\
\text { Were evaluated.Houndini Lock-lub was by } \\
\text { far the best release agent evaluated. }\end{array}$ \\
\hline
\end{tabular}




\section{References:}

${ }^{1}$ Research of the Effect of Lubrication on Extrusion Load in direct Extrusion, H. Sonmez, XVI IMEKO World Congress, Measurement - Supports Science - Improves Technology - Protects Environment ... and Provides Employment - Now and in the Future, Vienna, AUSTRIA, 2000, September 25-28

${ }^{2}$ Effect of Glass Lubrication Behavior on the Surface Quality of Extrudates in Glass-Lubricated Hot Extrusion, D. Damodaran, R. Shivpuri DIRP Annals., (46)1, 1997.

${ }^{3}$ Development of Complex Shapes Made by Titanium Extrusion, Dr. John Foltz, Mr. Gordon Dobbie , Ms. Caitlin Toohey, Dr. Andy Martinez, Aeromat 24th Advanced Conference and Exposition American Society for Metals, April 2013

${ }^{4}$ Extrusion of Uranium, Report: CT-953, E. C. Creuts, October 2, 1943

${ }^{5}$ Extrusion Lubrication, Paul Frost, US Patent 3,059,769, October 1962

${ }^{6}$ LINER FOR EXTRUSION BILLET CONTAINERS, S. A. Spachner, Report ASD-TDR-7-945 (II), 1962

${ }^{7}$ Forming Tubes and Rods of Uranium Metal by Extrusion, E. Creutz, US Patent 2,870,907, January 1959

${ }^{8}$ Refractory Die for Extruding Uranium, E. Cruetz, US Patent 2,899,054, August 1959

${ }^{9}$ High Energy Rate Extrusion of Uranium, L. Lewis, US Patent 3,098,0807, July 1963

${ }^{10}$ Theoretical and Experimental Study of the Glass Lubricated Extrusion Process, P. Baqué, J. Pantin and G. Jacob, Journal of Lubrication Technology, vol. 97, n.(1), pages: 18-23 (1975)

${ }^{11}$ Viscosity analysis of alkali metal carbonate molten salts at high temperature, Sun Woog KIM et.al., Journal of the Ceramic Society of Japan 123 [5] 355-358, 2015

${ }^{12}$ Solid-Liquid Phase Equilibria for Mixtures of Lithium, Sodium, and Potassium Carbonates, GEORGE J. JANZ and MAX R. LORENZ, Journal of Chemical and Engineering Data, VOL. 6, NO. 3, JULY 1961

${ }^{13}$ Coupled Experimental Study and Thermodynamic Modeling of Melting Point and Stability of Li2CO3Na2CO3-K2CO3 Based Salts, C. Chen et. al., , Journal of Solar Energy Engineering, AUGUST 2014, Vol. 136

14 THE IGNITION OF URANIUM, L. BAKER, JR., J. G. SCHNIZLEIN and J. D. BINGLE, Journal of Nuclear Materials, 20 (1966) 22-3

${ }^{15}$ Strength of Salt Core Composed of Alkali Carbonate and Alkali Chloride Mixtures Made by Casting Technique, Jun Yaokawa, Materials Transactions, Vol. 48, No. 5 (2007) pp. 1034 to 1041, 2007 Japan Foundary Engineering Society

${ }^{16}$ Effect of hardening methods of moulding sands with water glass on structure of bonding bridges, M. Stachowicz, ISSN (1897-3310) Volume 10, Issue 3/2010, 123 - 128 